\title{
Creating the 'Primitive': A Study of British Colonialism and Migrant 'Coolies' in the Tea Plantations of Assam Valley, 1860-1900
}

\author{
Anisha Bordoloi
}

\begin{abstract}
Most historical works have focused on the plantation as an economic venture which launched Assam on the passage of modernity with the advent of capitalism or as a political space defining the struggle between the workers and capitalists. This paper, however, views plantations as a political space where colonial ideas surrounding the 'modern' and the 'primitive' gets entrenched. This would help in understanding the deeper ramifications of the present condition of the labour community of plantations also known as 'coolie' who are mired in poverty, harsh working conditions and their treatment as outsiders in Assam even in the post-independence era of the country. It explores a complex process of subjugation which created and legitimized the kind of labour specific to the tea plantations of Assam. The paper views the plantations as a space where the relationship between the ruler and the ruled, the powerful and the powerless gets intensified.
\end{abstract}

Index Terms-Coolie, modern, primitive, tea plantations.

\section{INTRODUCTION}

Colonialism was made possible, and then sustained and strengthened, as much by cultural technologies of rule as it was by the more obvious and brutal modes of conquest that first established power on foreign shores. - Nicholas B. Dirks [1].

In the light of the above statement, it is necessary to break out of the usual means of superior arms, superior military organization, political power and economic wealth while reading the history of colonial conquest. Colonialism also needs to be understood as a cultural project of rule, especially, their dealing with colonized subjects such as tea plantation labourers through constructing categories for the subjects that eased the process of subjugation.

If some histories have focused on the triumphs, trials and entrepreneurial capabilities of the pioneers of tea industry such as Griffiths and Antrobus, then others like Varma, Bhowmik, Behal and Mohapatra have been mostly inclined to write the history of tea plantations from a Marxist perspective, thus, bracketing their study within the confines of labour history. My attempt through this paper is not to dismiss the claims made by these renowned scholars in the field of plantation history. Rather, it is an effort to contribute

Manuscript received May 5, 2014; revised July 9, 2014. The generous support lent by the Indian Council of Historical Research by awarding me the Junior Research Fellowship in August 2013 has enabled and motivated me to carry out research for this paper.

Anisha Bordoloi is with the Department of History, Faculty of Social Sciences University of Delhi, New Delhi (e-mail: anishabordoloi.8@gmail.com). further to the trove of knowledge that already exists in this discipline. I will try to provide new insights about the ways in which the tea plantation labour community can be viewed as well as deepen our understanding about an industry and its development in relation to the society because of which it exists.

\section{METHODOLOGY}

The paper is a culmination of both primary and secondary sources. The primary sources have been collected from the National Archives of India, New Delhi, these mostly being labour immigration reports and district emigration bills from the Emigration branch of Department of Agriculture, Revenue and Commerce and the Department of Revenue and Ariculture. Collection of data is primarily confined to colonial documents available for the districts of Darrang, Sibsagar and Lakhimpur in the region of Assam Valley from the time period of 1860 to 1900 . A thematic arrangement of data is followed instead of chronological.

\section{A. Central Question}

Given the extreme poverty, harsh working conditions and their treatment as outsiders by the local inhabitants of the region even in the post-independence era, it is important to see whether the tea plantation labourers in Assam are victims of a legacy left behind by colonialism given the fact that their recruitment into the tea plantations of Assam was begun in the colonial era.

\section{B. Objectives}

1) To understand the identity of the recruited population under the category 'coolie'.

2) To show the notion of 'primitivity' as crucial in categorizing a population in order to legitimize the differences between the ruler and the ruled, the colonizer and the colonized within the territorial confines of the tea garden.

3) Interaction between the dynamics of race, morality, law, patriarchy and paternalism to lend meaning to what has been identified as 'coolie' and the 'tea garden'.

\section{ANALYSIS AND INTERPRETATION}

\section{A. Recruitment of Tea Plantation Labour}

I begin by first providing a background to the recruitment process into the plantations. The initial forays of the tea companies into the labour market made them resort to 
Chinese, Naga, Singpho, Khamti and Kachari labourers although it very quickly proved to be a failed experiment. This was because the Chinese could not adjust with the harsh climatic and working conditions of the plantations, the Nagas, Singphos and Khamtis being 'wild, hill tribes' although were induced into work tended to disappear after few days, while the latter resorted to temporary work in the plantations in search of seasonal wage work [2]. The failure of colonial attempts to convert the ordinary cultivator in Assam into capitalist labour to work in the tea plantations earned the latter the nomenclature lazy native and forced tea planters to look for options beyond the western territory of Assam. This drove colonizers to select a particular type of population whose characteristics were bereft of 'laziness' and were obedient by nature. The mission to procure the suitable labour, commonly known in colonial vocabulary as the tea coolies, thus began.

What kind of community/communities were assumed to create the kind of labour specific to the plantations? If one were to reflect Jayeeta Sharma, the appropriateness of the immigrant coolie as ideal labour for tea gardens, was most explicitly expressed in the racialized sociology of labour, where the coolie, identified especially with the tribal junglee stood for docility and capability for hard manual labour against the intractability and laziness of the native [3]. Therefore, through movement across the western borders of Assam, 'suitable coolies' who were also displaced peasant communities such as the Santhals, Oraons, Mundas, Kols, Gonds, Konds and Kharias were procured from Bengal, Orissa, Chota Nagpur, United Provinces, Central Provinces, Nepal and even as far as Madras and Bombay [4]. Given the earlier occupation of these people as peasants in forested tracts, the laborious physical work required to clear the jungles of Assam along with the digging, hoeing and sowing activities that went into creating a plantation, officials and planters probably thought of the high possibilities of the ability of these tribal peasant communities to adapt to similar environs and work conditions in Assam.

The 'junglee' or the primitive from hilly, forested tracts of the Indian sub-continent other than Assam were devoid of any caste or religious restrictions unlike the Hindu and the Muslim cultivators of the plain areas in general. The absence of religious orientation devoid of restrictions provided the added advantage of the possibilities of bringing such sections of the population to a distant land such as Assam, thus giving rise to the emigrant coolie labour. The lack of rigidity arising out of caste and religious restrictions was seen as an indicator of the lack of a strong sense of identity and group solidarity which reflected the possibility of emigration out of their original homelands. The tea garden, thus, reflected an example of the colonial mission to civilize infused with a developmental capitalist logic and order where subjects such as the newly migrated labour community entered into a monotous time-work-discipline framework operational in several tea gardens and were organized into garden lines.

\section{B. Lure of Liquor}

The lure of liquor stood as a test of racial superiority and morality to determine the social position of the coolie population within the tea garden. Colonizers assumed the habit of drink to imply a high degree of corruption and looseness of character. If, on one hand, planters desired the labourers' refrain from the consumption of liquor in order to ensure the smooth functioning of the production process in a tea garden, then on the other hand, the setting up of a number of its licensed retailers in the vicinity of tea gardens and the neighbouring villages by the government has made many a planter to lament:

...the coolies, who, unable to resist the temptation put in their way, spend their hardly earned rupees in to a state of utter incapacity....it is evident to anyone that the effect on the future working of a garden must be terribly demoralizing [5].

The government, therefore, by choosing the sites of its liquor shops served the triple purpose of bringing to the fore, the immoral nature of the coolies, extracting revenue along with the cementing of its own idea surrounding the subjectsprimitive, backward, poor, uncultured and racially inferior. The restrictions imposed in an effort to curb the drinking of home-made liquor should be seen in the larger context of enforcing morality on the subjects by trying to streamline the behavior of the workers in order to suit the colonial order of things in a capitalist work regime. This could mean disrupting the cultural milieu within which the labour force tended to behave and endure.

Therefore, the concern over the excess consumption of alcohol which tended to hamper the 'time-work-discipline' structure of the plantation emphasized the 'coolie' nature of the workforce who did everything in excess, who did not have control over their temptations and hence, needed guidance through an enforcement of 'control' and 'discipline' by being admitted in 'rational' colonial institutions such as the garden hospital [6].

\section{Patriarchy or Paternalism}

Another informal way in which the planters entrenched their role as the dominant was through the portrayal of patriarchal and paternal roles in a colonial space such as the plantation. Very often one could not really differentiate patriarchy and paternalism from each other although some scholars talked about the planters' role as specifically paternal [7], [8]. With patriarchy, the planter's position in the tea garden was synonymous to the head of a family/ a system that was governed by a male authority. On the other hand, paternalism determined the planter's position as someone who treated his workers and catered to their needs as a father but by depriving them of their rights. Patriarchy cum paternalism personalized the relationship between the dominating and the dominated as such a relationship came to be based upon a paradox of sharpening the difference between the two polarities while at the same time blunting the physical distance between the two in order to reinforce domination through the building of a personal association with those who were selected to be dominated:

As we forged our way through the more than waist-high dripping wet tea, Jack corrected a woman here and there, cracked jokes with them mostly of the rather robust kind, and asked about their families and such things as the rice prospects on their holdings. Although he had only been in the country eighteen months, I was lucky to have him show me the ropes. He had the natives feeding out of his hand and 
could raise a laugh or a smile out of them at any time, whichis the way to handle native labour [9], [italics are mine].

The above portrays the development of a friendly attitude towards the labourers as a strategy to win their trust. By winning their trust, the subordinates' mind could be moulded to think and respond to the interests of the colonizer. A personalized nature of domination was also formed by the usage of the native language while dealing with them or when many a planter proudly claimed the usage of primitive methods to civilize the primitive [9].

\section{Colonial Law as a Means of Subjugation}

If the above are seen as indirect and informal ways of dehumanizing and exploiting labour, then a shift in focus needs to be directed towards the implication of colonial law as a formal, official and direct means of subjugation. Colonial law not only ensured the planters the freedom to choose for themselves but also for their coolies. As the plantation system in Assam was based on the system of indenture, planters could choose their freedom of contract with the protection of laws or through the system of examination, registration and special precautions in regard to contracts followed by a special penal law to make the coolies work out their contracts under the Labour District Emigration Bill [10]. Moreover, while discussing the nature of amendments made in the Bill, government officials like A. Mackenzie expressed their apprehensions in the proposals made by the government in the reduction of the planters' power over their coolies:

...the fifth amendment proposes to repeal the present power of planters themselves to seize runaway coolies. Without prejudging this question, His Honour would like much to learn what officers, planters and the coolies themselves say about it. The effect of the amendment would be that, instead of seizing his coolie, the master must prosecute him for desertion in the criminal court, under the third clause of section 123 of the amended Bill....The question is, whether the time has come when so great an interference with the liberty of the subject as this power of the master to seize can be dispensed with [10], [italics are mine].

The rationale invoked above to enforce the subjectivity of the coolie was done very much within the parameters of primitivizing the identity of the coolie in relation to upholding the power of the planters through a criminalization of the act of running away, establishing the right of the planters over their coolie and therefore, treating the coolie as the planter's property.

In fact, the total number of labourers imprisoned for crimes committed within the tea gardens and towards the plantation management in several plantations in Assam during the year 1876 was 26 while in 1877 it was 52. Of the 52 laborers imprisoned in 1877, 11 were convicted of offences against the general laws [4]. Therefore, subjectivity was imposed through terms and conditions defined by contractual agreements and designed and supported by the mechanism of law.

As tea gardens increased in number, so did the greater enforcement of control and discipline by the employers. This was accompanied by the increase in rioting and unlawful assembly [13]. The number of offences under Act V of 1861 rose from 32 in 1895 to 73 in 1896 [11]. This contributed towards easing the task of creating a primitive among the migrant labour community by creating a notion of uncivility around them. The fitness/unfitness antipodals were created not just by an examination of the coolies' adjustability with the climate of Assam but also by their ability to abide and be moulded by law.

The onslaught of industrialization began producing sections of population that represented extreme economic polarities of the rich and the poor. As the number of the poor began rising, their presence was felt more prominent not just in early modern Europe as shown by Yang [12], but also in the newly acquired colonies. The continuation of an imperialist capitalist structure was highly dependent on the existence of a large number of the poor so that colonialism could be represented as 'benevolence' to improve the lot of the poor as in the case of coolies in the numerous tea plantations of Assam.

Colonial law not only secured capitalist control over labour but it also acted as a cultural practice to prevent and guard 'civility' as against 'primitivity' within the same space of the plantation shared by both Europeans and non-Europeans. This also ensured racial distance infused with the purity/pollution dichotomy intact. Records of 'bad behaviour' by some such as desertions, habitual drunkenness and physical assaults on planters inside the plantations created the notion of criminality around an entire community.

Given the arrangement of contract which the emigrant entered as part of a system of indenture, the position of the emigrants was reduced to one of severe restrictions on their freedom and absolute dependency over their employers. As colonial law legalized the unfree status of the tea garden emigrant labour community in the plantations of Assam, the process of subjugation and dependency culminated into an unequal relationship between the colonial masters and the workers, so much so, that the workers in several tea gardens became the victims of immense inhuman treatment and brutality. The system of contract turned the position of the coolie as an object of ownership. In most colonial documents, a coolie is known by the contractor who supplied him/her, the planter who ruled over him/her, the garden that he/she lived in and the region that he/she hailed from. There is no information, whatsoever, about the coolies themselves. Thus, the identity of the patrons were entrenched upon a body provided by the coolie. He/ she could not be free unless the planter wished them to. Such a position of the tea garden coolies of Assam has compelled the nineteenth century English missionary Reverend Charles Dowding to aptly term the system as a 'thinly disguised slavery' [13]-[15].

The term 'coolie' as a pre-determined inferior categorization of a people dehumanized and commodified the position of the labourer as even against the will of the coolie,... extension of the contract was justified in order to prevent any damage to industrial interests [16].

\section{IMPLICATIONS}

The following implications can be derived from the study:

1) The findings depict that an absence of the voices of the migrant labourers was a major reason for creating a 
history of these people from above. Therefore, it is important to recover their voices to create a historical basis of their identity in order to entitle them to the Scheduled Tribe status which have long been denied to them.

2) Even today, the categorization of these people under the colonial term 'coolies' is one of the reasons for their exclusive treatment. Instead, the usage of the term 'tea labour community' seems suitable to avoid exclusionary treatment of this population.

3) It is also important for the government to create more effective laws to eradicate poverty among this community and thereby, ensure a dignified existence of these people.

\section{CONCLUSION}

The current study can be summed up with the following conclusions. Firstly, the conditions of poverty, dependency, humiliation, indignity, physical toil and injustice experienced by the labourers contributed towards the creation of the primitive tea coolie as a product of modernity. Secondly, its creation was a collaborative effort of both planters and government officials as part of a larger project of civilization in colonized lands. Thirdly, constructing categories such as coolie enabled colonizers to generalize the image of certain native populations. Fourth, the tea garden was a space where the primitive could serve as a site upon which the identity and superiority of the modern could be realized. Its creation was coterminous with the creation of colonial subjects and consolidation of empire in a frontier region like Assam. The absence of voice of the subjects themselves makes one come to the deduction that those who hold the reins of power play a major role in deducing ideas about its inhabitants and where they ought to be placed in the social and civilizational ladder depriving any sort of agency to natives to define themselves. This is precisely what defines the logic of a colonial tea 'garden' in Assam - a product of modernity sheltering the 'pre-modern' / the 'primitive'.

\section{ACKNOWLEDGMENT}

I am extremely grateful to the people and institutions that have helped me shape this paper. I am grateful to my supervisor, Prof. Amar Farooqui for his continuous support, encouragement and valuable insights into my writings. I thank the History Department of the University of Delhi for believing in my capabilities as a research scholar and helping me pursue a career in historical research. I express my gratitude to the library and staff of the National Archives of India, the Central Reference and Ratan Tata libraries of the University of Delhi, Nehru Memorial Museum and Library, Indian Council of Historical Research and the District Library of Guwahati, Assam for letting me access their rich treasure of valuable sources. I wish to thank my parents for their love, inspiration, undivided support and encouragement to chase my dreams and helping me become the person I am today. Last, but not least, Raktim, my better half, whose selfless love, support, motivation, cheerful demeanour and sacrifice has kept me going in this journey called life.

\section{REFERENCES}

[1] N. B. Dirks, Castes of Mind: Colonialism and the Making of Modern India, Princeton: Princeton University Press, 2001, p. 9.

[2] J. Sharma. (April 14, 2006). Growing tea: lazy natives and colonialism's coolies. Agrarian Studies Colloquium. [Online]. pp. 4-7. Available: www.yale.edu/agrarianstudies/colloqpapers/24sharma.pdf

[3] J. Sharma, "Lazy natives, coolie labour and the Assam tea industry," Modern Asian Studies, vol. 43, issue 6, pp. 1287-1324, Nov. 2009.

[4] Annual Report on the Labour Immigration into Assam for the Year 1877, Proceedings of the Deptt of Revenue, Agriculture and Commerce, Dec 1878 .

[5] G. M. Barker, Tea Planter's Life in Assam, Calcutta: Thacker, Spink \& Co., 1884, p. 181.

[6] N. Varma, "For the drink of the nation: drink, labour and plantation capitalism in the colonial tea gardens of Assam in the late nineteenth and early twentieth century," in Labour Matters Towards Global Histories, M. V. der Linden and P. P. Mohapatra, Ed. New Delhi: Tulika Books, 2009, pp. 295-313.

[7] J. Breman, Taming the Coolie Beast: Plantation Society and the Colonial Order in Southeast Asia, Oxford: Oxford University Press, 1989, pp. 75-140.

[8] R. P. Behal, "Coolie drivers or benevolent paternalists? British tea planters in Assam and the indenture labour system," Modern Asian Studies, vol. 44, issue 01, pp. 29-51, Jan. 2010.

[9] J. M. Scott, The Tea Story, London: William Heimann Ltd., 1964, pp. 164-165.

[10] Report on Labour Immigration into Assam for the Year 1896, Extract from the Proceedings of the Government of India, No. 2 - 80-2, dated the 8th January 1898, Revenue and Agriculture Deptt, Emigration Branch.

[11] Bengal Labour District Emigration Bill [ Progs. Nos. 22 to 25]. FromA. Mackenzie, Officiating Secretary to the Government of Bengal, Judicial Deptt. To- The Commissioner of the Assam Division, To- The Commissioner of the Dacca Division, Nos. 3705 \& 3706, dated the 19th September 1873, Proceedings of the Deptt. of Agriculture, Revenue and Commerce, October, 1873.

[12] A. A. Yang (ed), Crime and Criminality in British India, Tucson, Arizona: The University of Arizona Press, 1985, p. 10.

[13] "Tea-Garden Coolies in Assam"- A Letter by Hon'ble J.Buckingham, C. I. E, replying to a communication on the subject, which appeared in the "Indian Churchman", The whole reprinted with introduction and an answer by The Rev. Charles Dowding, Thacker, Spink \& Co, Calcutta, 1894 , pp. 31.

[14] P. P. Mohapatra and R. P. Behal, "Tea and money versus human life: the rise and fall of the indenture system in the Assam tea plantations, 1840-1908," in Plantations, Proletarians and Peasants in Colonial Asia, E. V. Daniel, H. Bernstein and T. Brass, Ed. London: Frank Cass, 1992, pp. 142-172.

[15] R. P. Behal, "Coolie drivers or benevolent paternalists? British tea planters in Assam and the indenture labour system," Modern Asian Studies, vol. 44, special issue 01, pp. 29-51, Jan 2010.

[16] J. Breman, Taming the Coolie Beast: Plantation Society and the Colonial Order in Southeast Asia, Oxford: Oxford University Press, 1989, pp. 75-140.

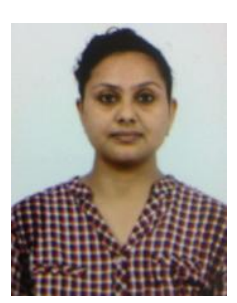

Anisha Bordoloi is a Ph. D. scholar in the Departmen of History, University of Delhi, pursuing research on the topic culture and identity in Assam: Historicizing Tea Plantations. She completed her matriculation and senior secondary examinations from Delhi Public School, Numaligarh, Assam in 2002 and 2004 respectively and went on to complete graduation in history (Hons.) from Lady Sri Ram College, New Delhi in 2007. Bordoloi earned her master's degree with specialization in modern Indian history in 2009 from the University of Delhi, New Delhi.

She joined as a university teaching assistant from 2010-2012, Department of History, University of Delhi; She was associated in the $70^{\text {th }}$ session of the Indian history congress organized by the University of Delhi, May, 2010 and involved in the international seminar on "Taj Mahal - A Symbol of Indo-Iran Craftsmanship", jointly organized by University of Delhi, Indian council of historical research and Iran culture house, New Delhi in October, 2009. She has two book reviews as publications and one paper presentation to her credit. Her research interests lie in the history of north-east India, particularly Assam and its tea plantation industry.

The author is currently a recipient of the junior research fellowship granted by the Indian council of historical research. 